\title{
Benthic habitat properties can delay settlement in an estuarine fish (Sciaenops ocellatus)
}

\author{
Lisa N. Havel ${ }^{1,2, *}$, Lee A. Fuiman ${ }^{1}$, Alfredo F. Ojanguren ${ }^{1,3}$ \\ ${ }^{1}$ Marine Science Institute, The University of Texas at Austin, 750 Channel View Drive, Port Aransas, TX 78373, USA \\ ${ }^{2}$ Present address: Atlantic States Marine Fisheries Commission, 1050 N. Highland St. Suite 200 A-N, Arlington, VA 22201, USA \\ ${ }^{3}$ Present address: School of Biology, University of St Andrews, Fife KY16 9ST, UK
}

\begin{abstract}
Settlement is the last stage of high mortality in the life cycle of demersal marine fishes, making the number of larvae that successfully settle to a benthic habitat a predictor of future population size. Habitat selection is an active settlement process for coral reef fishes, however, there has been less research about settlement in other ecosystems. This study used laboratory and field experiments to examine the relationship between size and settlement over various substrates in red drum Sciaenops ocellatus, a temperate and subtropical estuarine species. In the laboratory, vertical position of fish (4.3 to $40.0 \mathrm{~mm}$ standard length [SL]) was recorded in the presence of sand, oyster shells, or seagrass to determine median settlement size. Median settlement size was $12.9 \mathrm{~mm}$ SL for seagrass, $15.8 \mathrm{~mm}$ SL for sand, and $20.5 \mathrm{~mm}$ SL for oyster shells. To determine the size at which fish settle in the wild, vertically partitioned field enclosures were used to separate individuals (5.2 to $37.3 \mathrm{~mm} \mathrm{SL}$ ) in the water column ( $>16 \mathrm{~cm}$ from the sediment) from those in the seagrass $(<16 \mathrm{~cm}$ from the sediment). Larvae in the water column were smaller than in the seagrass ( 9.3 vs. $14.3 \mathrm{~mm} \mathrm{SL}$ ). Previous studies reported that red drum reach nursery habitats at $4 \mathrm{~mm} \mathrm{SL}$, but this study suggests that they do not use structured habitats at first. Instead, this fish settles at different sizes to various habitats, which can be interpreted as evidence for active settlement.
\end{abstract}

KEY WORDS: Habitat preference $\cdot$ Substrate $\cdot$ Fish larvae $\cdot$ Seagrass $\cdot$ Red drum

\section{INTRODUCTION}

Many marine organisms have bipartite life histories consisting of a pelagic larval phase followed by demersal juvenile and adult phases. The shift from the pelagic to the benthic environment, known as settlement, occurs when an individual outgrows the ability to exploit water-column resources, thus changing to a substrate-associated niche (Werner 1988). Settlement is usually the last stage of high mortality in the life cycle, at times exceeding $50 \%$ within the first $24 \mathrm{~h}$ of association with the benthos (Doherty et al. 2004, Fuiman et al. 2010, McCormick \& Meekan 2010). Therefore, success or failure around the time of settlement contributes to the

${ }^{*}$ Corresponding author: lhavel@asmfc.org order-of-magnitude variations in adult population sizes across spatial and temporal scales, which greatly impact fisheries and local ecology (Cowan \& Shaw 2002).

Settlement is generally considered to be a swift process in order to reduce mortality risk (Wilbur 1980, Victor 1982, Bell \& Westoby 1986). Nevertheless, a few studies on coral reef fishes have found that the settlement transition can last for several weeks (Breitburg 1989, Kaufman et al. 1992, McCormick \& Makey 1997, Lecchini et al. 2012, White et al. 2013). While specific habitats may be critical for the survival of new settlers of some species, it is more likely that juvenile fishes can use a range of habitats (Butler \& Jernakoff 1999, Petrik et al. 1999). Wetlands (i.e. salt

() The authors 2015. Open Access under Creative Commons by Attribution Licence. Use, distribution and reproduction are unrestricted. Authors and original publication must be credited. 
marshes and mangroves) and seagrass beds are the most commonly studied nursery habitats, but oyster reefs, rocky substrata, or sand flats might be occupied by juveniles as well (Orth et al. 1984, Beck et al. 2001, Neahr et al. 2010).

Bell \& Westoby (1986) suggested that while different microhabitats within nursery grounds could result in varying degrees of fitness for residents, an individual that is competent to settle should settle onto the first structured substrate it encounters, regardless of quality. According to this 'settle-andstay' hypothesis, rejecting the first site encountered would result in an increased risk of predation, since any benthic structure is safer than the water column (Bell \& Westoby 1986). Organisms are expected to seek out more suitable microhabitats within the expanse of substrate after initial settlement, even though moving across unvegetated areas could also increase predation risk (Bell \& Westoby 1986). When the second half of this hypothesis was tested in temperate estuaries, it was discovered that settled individuals do emigrate over expanses of unvegetated substrate to artificial seagrass, contrasting with the settle-and-stay hypothesis (Sogard 1989).

Aside from the few studies on coral reef fishes, most studies on habitat preference during settlement in marine fishes have consisted of observations and collections of settled individuals (e.g. Sogard 1989, Lubbers et al. 1990, Gray et al. 1996, Nagelkerken et al. 2000, Jenkins \& Hamer 2001, Espino et al. 2011). While these studies are useful for understanding recruitment, they cannot explain the factors that influenced settlement and the resulting spatial distribution of juveniles. For example, the distribution of juveniles in benthic habitats could be the result of individuals actively searching for a specific habitat during the settlement process, or moving to a habitat based on intra- or inter-specific competition or prey availability (Nakayama et al. 2011). Alternatively, new recruits could be settling randomly regardless of habitat, with those in higher quality habitats profiting from greater resistance to hydrodynamics (i.e. less likely to be flushed out of the system) or lower post-settlement mortality compared to those in surrounding habitats.

The main objective of this study was to determine if the first prediction of the settle-and-stay hypothesis proposed by Bell \& Westoby (1986) applies to a temperate and subtropical estuarine fish species, the red drum Sciaenops ocellatus, as suggested by Stunz et al. (2002b). The vertical distribution of larvae over a range of sizes was tested both in the field and laboratory to determine mean size at set- tlement and settlement behavior. For this experiment, settlement was operationally defined as spending $>50 \%$ of the first $5 \mathrm{~min}$ of habitat encounter in $\leq 2 \mathrm{~cm}$ of the uppermost portion of the habitat. In the laboratory, the settlement size of larvae was tested over 3 potential nursery substrates (sand, seagrass, and oyster shells). The settle-andstay hypothesis predicts no difference in larval size at settlement among structured (seagrass and oyster shells) substrates. Differences in settlement size among the 3 substrates would indicate delayed settlement and the potential for active habitat selection in this species. By actively delaying settlement, red drum would not be settling to the first structure available, and thus not following the first half of the settle-and-stay hypothesis. We tested the mean size at settlement for wild red drum in the field over seagrass beds in situ. These findings fill in a critical gap in the understanding of marine fish settlement, and have implications for management of estuarine fisheries.

\section{MATERIALS AND METHODS}

\section{Study species}

Red drum occur in the Gulf of Mexico and Atlantic waters of North America as far north as Massachusetts, though are rarely caught north of New Jersey (Beckman et al. 1988, Hoese \& Moore 1998, Atlantic States Marine Fisheries Commission 2009). Males reach maturity in $3 \mathrm{yr}$ and females in $5 \mathrm{yr}$, at about $70 \mathrm{~cm}$ fork length (Hoese \& Moore 1998). In Texas waters, they form spawning aggregations offshore or along the coast during the fall. Eggs and young larvae are brought into estuaries by tidal currents (Holt et al. 1983, 1989). Larvae spend approximately $3 \mathrm{wk}$ in the pelagic phase before appearing in shallow ( 0 to $2 \mathrm{~m}$ depth) seagrass beds, marsh edges, or unvegetated bottom (at about $7 \mathrm{~mm}$ standard length [SL]; Holt et al. 1983, Stunz et al. 2002a, Pérez-Domínguez 2004). Upon arrival, they have not yet reached the juvenile stage (i.e. complete squamation, which occurs at 20 to $23 \mathrm{~mm} \mathrm{SL}$ ), but are experiencing rapid changes in eye development. These include increases in angular rod cell density, focal length, pupil area, relative retinal illuminance, and photoreceptor: ganglion ratio (Fuiman \& Delbos 1998). Together, these developmental changes result in reduced light intensity thresholds for the larvae, which can increase the ability to see in the lower light environments of the benthos. Red drum spend the remainder of their 
subadult phase in these estuaries and move offshore as adults in the fall and winter (Pattillo et al. 1997). Larvae in this experiment were tested over a range of sizes from planktonic to the maximum size found in seagrass beds during the spawning season ( 40 mm $\mathrm{SL})$. This range was chosen to ensure the settlement size was captured over the course of the experiments.

\section{Laboratory study}

\section{Larval rearing}

A total of 4 batches of eggs (group of eggs collected from one adult tank on a given day) were collected from captive adults maintained at the Texas Parks and Wildlife Department's Marine Development Center in Corpus Christi (19 and 29 August, and 9 and 26 September 2011), and a fifth batch was collected from captive adults maintained at the University of Texas Marine Science Institute's Fisheries and Mariculture Laboratory (FAML) in Port Aransas (27 October 2011). Each tank of adults included several males and females, so it was impossible to determine whether one batch of eggs was from one or multiple females, or if batches from different days were from the same parents. Spawning occurred in the evening and eggs were collected the following morning. A subsample of approximately $10000(10 \mathrm{ml})$ viable (floating) eggs from each spawn was equally divided into two $150 \mathrm{l}$ fiberglass conical tanks filled with seawater, where they remained until experimentation. All water for rearing and experimentation was maintained at a temperature of $27^{\circ} \mathrm{C}$ and salinity of 35 to 40 with a continuous supply of oxygen through an airstone. The photoperiod was $12 \mathrm{~h}$ light: $12 \mathrm{~h}$ dark. Larvae hatched the same afternoon and were fed rotifers (Brachionus sp.) enriched for $45 \mathrm{~min}$ in the fatty acid supplement Algamac 3050 (Aqua-fauna Bio-Marine) from 1 day post-hatching (dph) until $11 \mathrm{dph}$ at a concentration of approximately $2667 \mathrm{l}^{-1}$. At 10 and $11 \mathrm{dph}$, larvae were also fed $1 \mathrm{~d}$ old Artemia sp. nauplii at a concentration of approximately $67 \mathrm{l}^{-1}$. At $12 \mathrm{dph}$, the larvae switched to a diet of $2 \mathrm{~d}$ old Artemia sp. nauplii enriched for $16 \mathrm{~h}$ in Algamac 3050 at a concentration of approximately $400 \mathrm{l}^{-1}$, and continued that diet until testing, supplemented once a day with 1 to $3 \mathrm{~g}$ of Ottohime (Reed Mariculture) after $20 \mathrm{dph}$. Feeding took place once a day between 08:00 and 10:00 h. In the holding tanks, larvae larger than ca. $15 \mathrm{~mm}$ SL settled to the bottom of the tank, and, while mortality was not measured, cannibalism was observed.

\section{Experimental procedure}

The afternoon before testing, larvae were transferred from the rearing facilities to the laboratory in a covered 151 bucket filled with seawater. This overnight acclimation was implemented to bring stress levels back to basal levels after transfer (Robertson et al. 1988). The larvae were then put into individual 11 beakers filled with $300 \mathrm{ml}$ of seawater and placed in a water bath to maintain constant temperature. The testing chamber consisted of a glass aquarium $150 \times$ $31 \times 50 \mathrm{~cm}$ (length $\times$ width $\times$ depth) divided into 3 sections $(50 \times 31 \times 50 \mathrm{~cm})$ by sturdy black plastic so that 3 larvae could be tested at one time. The chamber was filled with filtered seawater (temperature was maintained by 2 underwater heaters that were removed during the experimental procedure). The bottom of the tank was covered by 1 of 3 substrate materials: shoalgrass (Halodule wrightii), eastern oyster (Crassostrea virginica) shells, or sand (control). Only 1 substrate covered all 3 sections at a time. $H$. wrightii reached $14 \mathrm{~cm}$ into the water column while C. virginica reached $4 \mathrm{~cm}$ into the water column. Three sides of each chamber were covered in black plastic and the fourth side was transparent glass for surveillance. Depth was marked by black lines that extended $4 \mathrm{~cm}$ from both the left and right sides of the tank in $2 \mathrm{~cm}$ increments. The room was dark except for two $60 \mathrm{~W}$ incandescent bulbs placed $60 \mathrm{~cm}$ above the tank $30 \mathrm{~cm}$ apart to allow for the fish to see its surroundings without seeing the observer. The substrate and water were changed every $4 \mathrm{~d}$ and the tank was cleaned 3 times with freshwater. Dry sand was collected from the local beach in Port Aransas, and the seagrass (including roots, rhizomes, epiphytes and potential red drum prey located on seagrass blades, as well as surrounding sediment) and oyster shells were collected from Harbor Island, Texas $\left(27^{\circ} 53^{\prime} \mathrm{N}, 97^{\circ} 7^{\prime} \mathrm{W}\right)$. The sand and seagrass were used for trials immediately following collection, and replaced every $4 \mathrm{~d}$. Oyster shells were collected at the beginning of the experiment, washed with freshwater 3 times, and dried for $2 \mathrm{~d}$ in the sun. They were washed and reused after a $4 \mathrm{~d}$ span.

Larvae were transferred to the testing chamber by slowly immersing a beaker containing an individual into each of the 3 chambers of the tank. The fish were allowed to adjust for $5 \mathrm{~min}$, after which their depth was recorded to the nearest $5 \mathrm{~cm}$ every $10 \mathrm{~s}$ for an additional 5 min (31 observations total). Five min was chosen for the testing period to capture the initial settlement behavior of the individual as opposed to post-settlement behavior, and because preliminary 
trials indicated that there were no differences in vertical distribution between $5 \mathrm{~min}$ and $1 \mathrm{~h}$. From these observations, the median distance from the settlement zone (the top of the substrate $+2 \mathrm{~cm}$ ), the variability between individuals in median distance from the settled habitat, and whether or not they settled were calculated. Each larva was sacrificed with an overdose of tricaine methansulfonate (MS-222), photographed under a dissecting microscope after the experiment, and SL was measured using Image Processing and Analysis in Java (ImageJ, US National Institutes of Health) software.

\section{Field experiment}

Experiments were conducted off of Harbor Island, Texas 6 times during the spawning season, from 6 October to 18 November 2010 between 13:00 and 16:00 h. The site is a typical low-energy environment with shallow water and a flat bottom. Substrates transition from sand/mud and $H$. wrightii to turtle grass (Thalassia testudinum) at around $1 \mathrm{~m}$ water depth, and the $T$. testudinum grows in a maximum water depth of $2 \mathrm{~m}$. The study site was chosen because it was both easily accessible and had a steady supply of newly recruited red drum in previous years (authors' pers. obs.), which identified it as a suitable settlement habitat.

Red drum larvae were collected from nearby $H$. wrightii beds and the overlying water column using an epibenthic sled $(1 \times 1 \times 20 \mathrm{~m}$; width $\times$ height $\times$ net and rope tow length) and then transferred to a $60 \times$ $32 \times 25 \mathrm{~cm}$ (length $\times$ width $\times$ depth) bucket for sorting. Red drum ranged in size from 4.5 to $43.2 \mathrm{~mm} \mathrm{SL}$ (average $=11.0 \pm 6.4 \mathrm{SD})$. Ten random larvae were placed in a petri dish and photographed on shore, and size measurements were made using ImageJ in the laboratory. These 10 larvae were carried to and placed within 1 of the 3 small field enclosures and left undisturbed for $30 \mathrm{~min}$.

The small field enclosures were designed to separately sample larvae above and below the seagrass canopy. They were constructed from 4 vertical steel rods $(1.90 \mathrm{~cm}$ diam. $\times 100 \mathrm{~cm}$ long) and 3 steel rods (1.3 cm diam.) bent into rings $(92 \mathrm{~cm}$ diam.) positioned at 11, 27, and $91 \mathrm{~cm}$ from the bottom to form a cylindrical structure (Fig. 1). Gray mesh with $1.3 \times$ $1.1 \mathrm{~mm}$ (length $\times$ width) openings was attached to the lower 2 steel rings, with excess mesh flaring out of the bottom as a skirt to minimize escape of larvae from below. Mesh was also fastened to the top steel ring and allowed to drape down past the middle ring. When in the water (at a depth of $\sim 0.4 \mathrm{~m}$ ), the draped mesh on the upper ring was temporarily attached to the mesh on the lower rings to form a single cylindrical enclosure. A rope sewn into a loop at the bottom of the mesh attached to the upper ring acted as a drawstring. These field enclosures were placed in $H$. wrightii beds, where the water depth was approximately $40 \mathrm{~cm}$ above the seagrass canopy, and the drawstring of the enclosure was positioned at the top of the $H$. wrightii canopy such that the enclosure above the drawstring surrounded the water column, while the enclosure below the drawstring surrounded the seagrass bed.

After 30 min, 2 researchers removed the temporary attachments on the draped mesh and pulled the drawstring closed. The pulling of the drawstring left enough space between the upper portion of the enclosure (the water column section) and the lower portion (seagrass section) for a third researcher to hold a net made of gray mesh at the air/water interface to catch any fish in the water column that might have escaped from the drawstring. Immediately after the upper water column was enclosed, all larvae

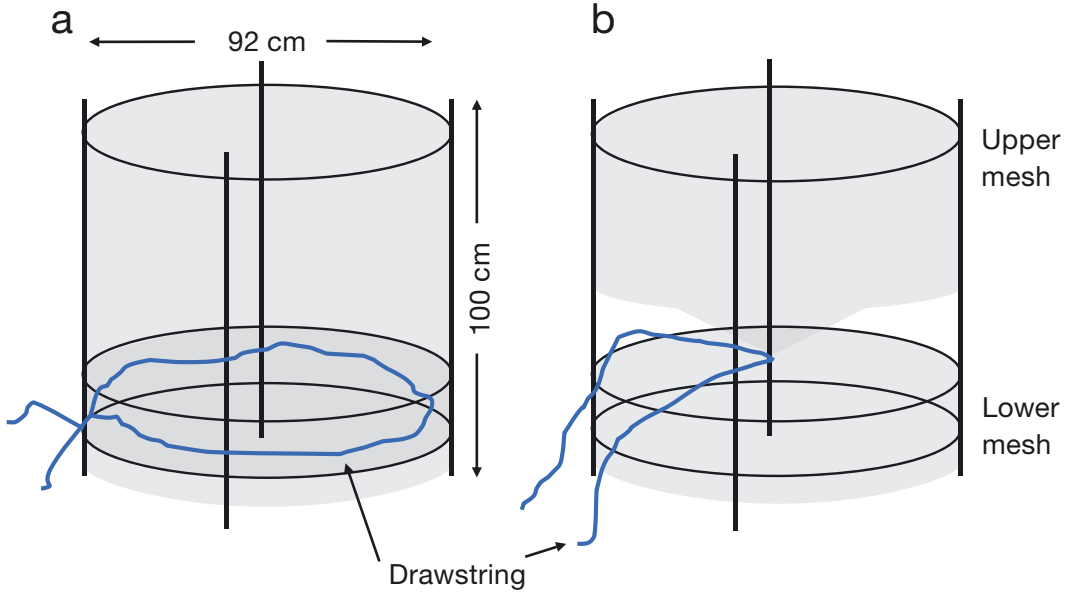

Fig. 1. Field enclosure made of 4 vertical steel rods and 3 steel rods bent into circles positioned 11, 27, and $91 \mathrm{~cm}$ from the bottom. Gray mesh was attached to the bottom 2 steel circles. Mesh was also attached to the top steel circle and draped down, with a rope sewn into the bottom to act as a drawstring. When in the water, (a) the draped mesh was temporarily attached to the lower mesh to seal the field enclosure, and (b) the drawstring was pulled shut to separate red drum Sciaenops ocellatus larvae in the water column from those in the seagrass bed 
found within both halves of the enclosure were collected with dip nets, kept separate, and taken to shore and photographed (for measurement of SL using ImageJ in the laboratory). Fish that were not recovered from the field enclosure were excluded from the analyses. Over the course of the season, 27 field enclosure trials were run.

\section{Statistical analyses}

Statistical analyses were performed with the R statistical package (v.3.0.2; R Foundation for Statistical Computing; www.R-project.org/). In the laboratory experiment, small fish occupied a position high in the water column and larger fish occupied a position close to the bottom, regardless of substrate type. Data for pre-settlement and transitioning individuals (those above the settlement zone, with a median distance from the top of the substrate $>2 \mathrm{~cm}$ ) were used in an ANCOVA (with substrate as the treatment and size as the covariate) to test for differences in settlement rate (slope) among the 3 substrates. To test for a change in variability in vertical position with size, the residuals from the regressions of vertical position on size for each treatment were used. Because the residuals were normally distributed with a mean of zero, their absolute value was then used in another ANCOVA (Lewontin 1966).

For both ANCOVAs, parametric assumptions were tested by graphical representation. Multiple $t$-tests with Bonferroni corrections were used for post-hoc analyses of the ANCOVAs. A logistic regression was applied to the 3 substrates separately to determine the probability of settlement at a given fish size for all individuals tested, where settlement was defined when a fish's median distance from the bottom was $\leq 2 \mathrm{~cm}$ above the top of the substrate (therefore settlement was defined as $\leq 16 \mathrm{~cm}$ for seagrass, $\leq 6 \mathrm{~cm}$ for oyster, and $\leq 2 \mathrm{~cm}$ for sand). This was performed with the 'aod' package (Lesnoff \& Lancelot 2012). Combined results from the 3 statistical analyses were interpreted for strength of attraction to benthic habitats.

For the field experiment, results from the 27 enclosures were combined for all analyses. A Welch's $t$-test was used to test for a size difference in larvae collected in the water column versus the seagrass (Ruxton 2006). A logistic regression (with the 'aod' package; Lesnoff \& Lancelot 2012) was applied to the individual fish to determine the probability of settlement for a fish at a given size in the field enclosures. To determine if there was a difference in settlement size for seagrass substrate between the laboratory and field experiments, a general linear model was used (binary dependent variable $=$ settled, treatment $=$ experimental location, covariate $=$ size).

\section{RESULTS}

\section{Laboratory experiment}

In total, 368 fish were tested in the laboratory experiment (98 in seagrass, 132 in oyster shells, 138 in sand), with sizes ranging from 4.3 to $40.0 \mathrm{~mm} \mathrm{SL}$ (median $=10.6,14.5$, and $12.2 \mathrm{~mm}$ SL for seagrass, sand, and oyster shells, respectively). Of those 368 fish, 229 (48 in seagrass, 93 in oyster shells, 88 in sand) were pre-settlement and transitional larvae (i.e. did not settle).

Both size $(\mathrm{p}<0.001, \mathrm{df}=1)$ and substrate $(\mathrm{p}<0.01$, $\mathrm{df}=2$ ) affected the vertical position in the water column for transitioning larvae, but the interaction between the 2 variables was not significant $(p=0.25$, $\mathrm{df}=2$; Fig. 2). Larvae over seagrass were closer to the substrate $($ mean $=11.5 \mathrm{~cm}$ from settlement zone) than larvae over oyster shells (mean $=16.8 \mathrm{~cm}, \mathrm{p}<0.05)$, but not sand $($ mean $=14.1 \mathrm{~cm}, \mathrm{p}=0.45)$. Additionally,
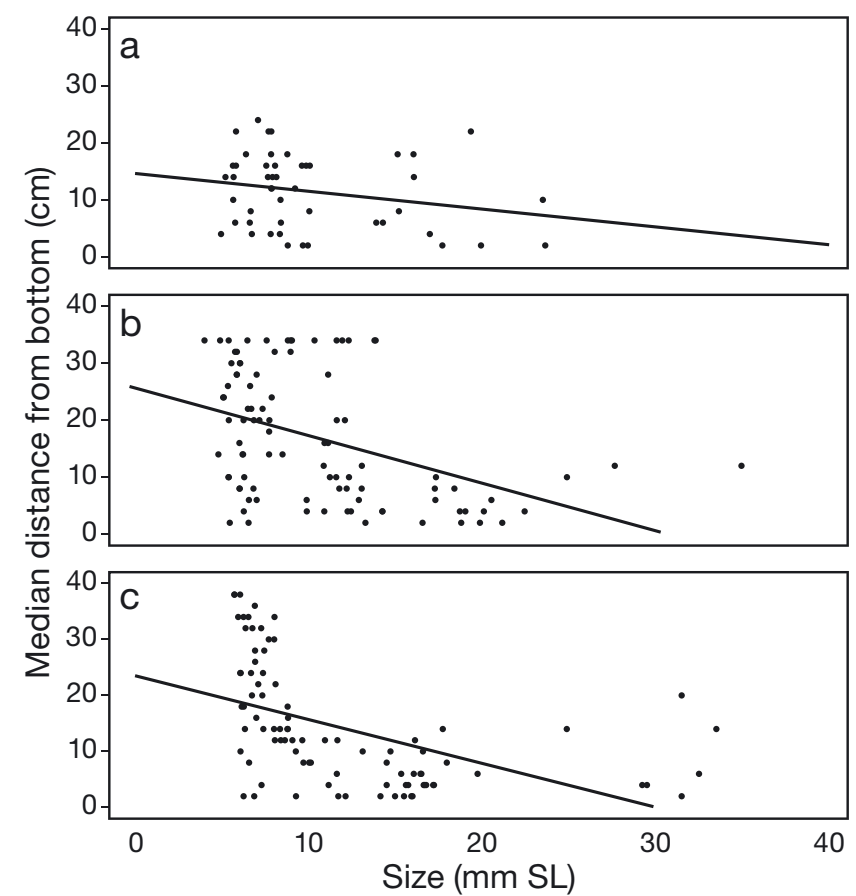

Fig. 2. Vertical position in the water column as a function of red drum Sciaenops ocellatus size in tank experiments over 3 substrates: (a) seagrass $(\mathrm{n}=48)$, (b) oyster shells $(\mathrm{n}=93)$, (c) sand $(n=88)$. Each point represents the median vertical position from the settlement zone of 31 measurements made during a 5 min period for an individual fish 
only smaller larvae over sand and oyster shells were found at the surface, whereas some larvae of all sizes were at the surface over seagrass. Vertical position variability was affected by substrate $(\mathrm{p}<0.001, \mathrm{df}=$ $2)$, but not by size $(p=0.31, d f=1)$ or the interaction $(p=0.66, d f=2$; Fig. 3). Pre-settlement larvae over seagrass were less variable in their vertical position $($ mean $=5.32 \mathrm{~cm})$ compared with larvae over sand $($ mean $=7.73 \mathrm{~cm}, \mathrm{p}<0.05)$ and oyster shells $($ mean $=$ $8.77 \mathrm{~cm}, \mathrm{p}<0.001)$.

Both size and substrate had highly significant effects on whether an individual was considered settled (logistical regression, $\mathrm{p}<0.001$ for size and substrate). The responses of fish in the oyster shell habitat were different from those in the sand and seagrass habitats $(p<0.01)$, however the individuals in the seagrass treatment did not settle at a different size from those in the sand ( $p=0.07$; Fig. 4). For a fish of $14.3 \mathrm{~mm} \mathrm{SL}$ (the mean size of the fish tested in this experiment), the probability of being settled on the oyster substrate was $0.24,0.43$ on sand, and 0.57 in seagrass. The predicted median sizes at settlement were $20.5 \mathrm{~mm}$ SL in oyster shells, $15.8 \mathrm{~mm}$ SL in sand, and $12.9 \mathrm{~mm}$ SL in seagrass. The major difference in the results between the ANCOVA (median

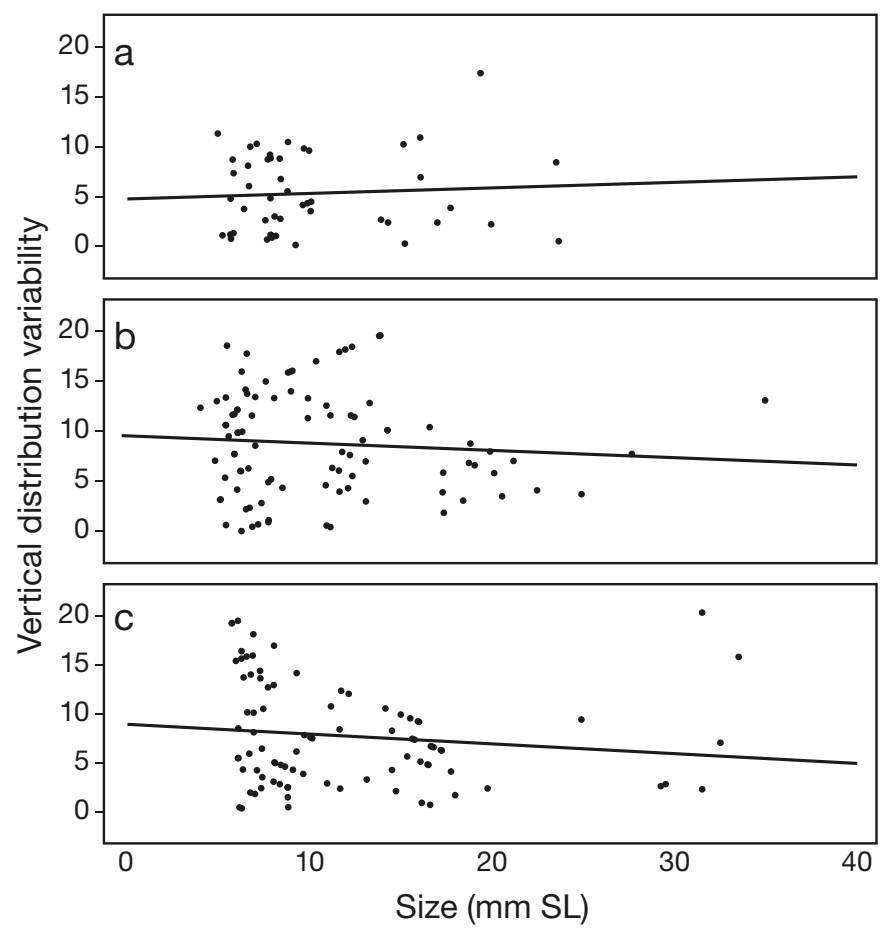

Fig. 3. Variability in median vertical position with size in presettlement and transitional red drum Sciaenops ocellatus in tank experiments over 3 substrates: (a) seagrass, (b) oyster shells, (c) sand. Variability is defined as the absolute value of the residuals from the ANCOVA on median distance from the settlement zone distance from the bottom) and the logistical regression (settlement) is due to the differences in habitat structure height and their overlying water column. For example, a fish with a greater median distance from the bottom in seagrass than in sand would still be within the habitat, and thus considered settled to it. These differences will be interpreted in depth in the 'Discussion'.

Upon introduction to the testing chamber, red drum either explored their surroundings or quickly swam to the substrate and moved minimally in the vertical position for the remainder of the experiment (L. N. Havel pers. obs.). They did not appear stressed, which can be characterized by rapid bursts of swimming, especially up and down the side of the tank (L. N. Havel pers. obs.).

\section{Field experiment}

Of the 273 fish tested in the field experiment, 143 $(52.4 \%)$ were recovered (80 in the water column and 63 in the seagrass beds). Recovered fish ranged in size from 5.2 to $37.3 \mathrm{~mm}$ SL (mean $=11.5 \mathrm{~mm} \mathrm{SL}$ ). Mean size of fish recovered from the water column was smaller than those recovered from the seagrass $(9.3 \pm 2.53$ vs. $14.3 \pm 7.39$ mm SL, p $<0.001$; Fig. 5) .

Size had a highly significant effect on settlement $(\mathrm{p}<0.001$; Fig. 5). For every $1 \mathrm{~mm}$ increase in SL, the

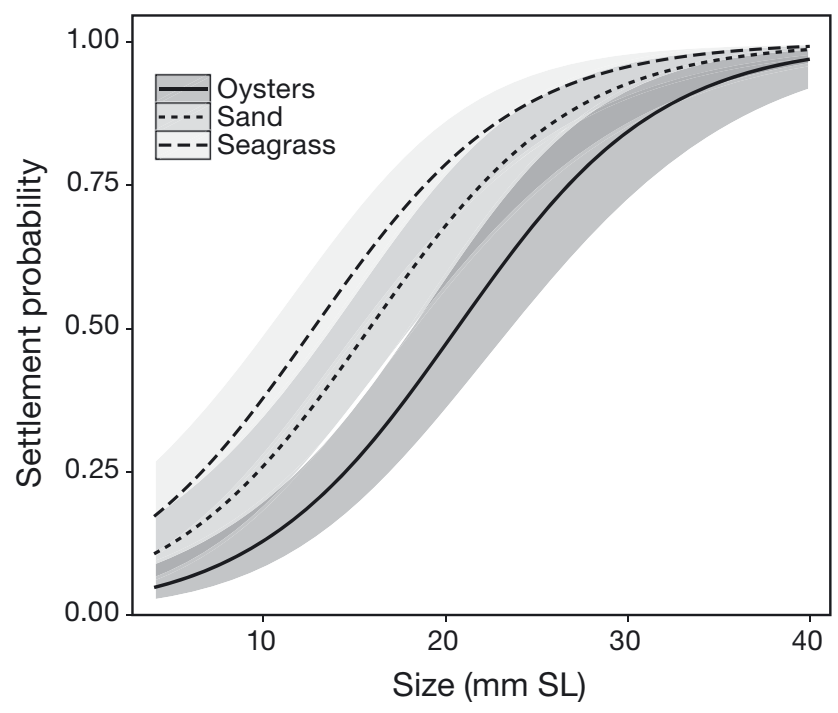

Fig. 4. Probability of red drum Sciaenops ocellatus settlement as a function of size in seagrass, oyster shells, and sand substrates in tank experiments. Median size at settlement ( $50 \%$ probability) was $20.5,12.9$, and $15.8 \mathrm{~mm}$ SL for fish in oyster shells, seagrass, and sand, respectively. Shading represents $95 \%$ confidence intervals 


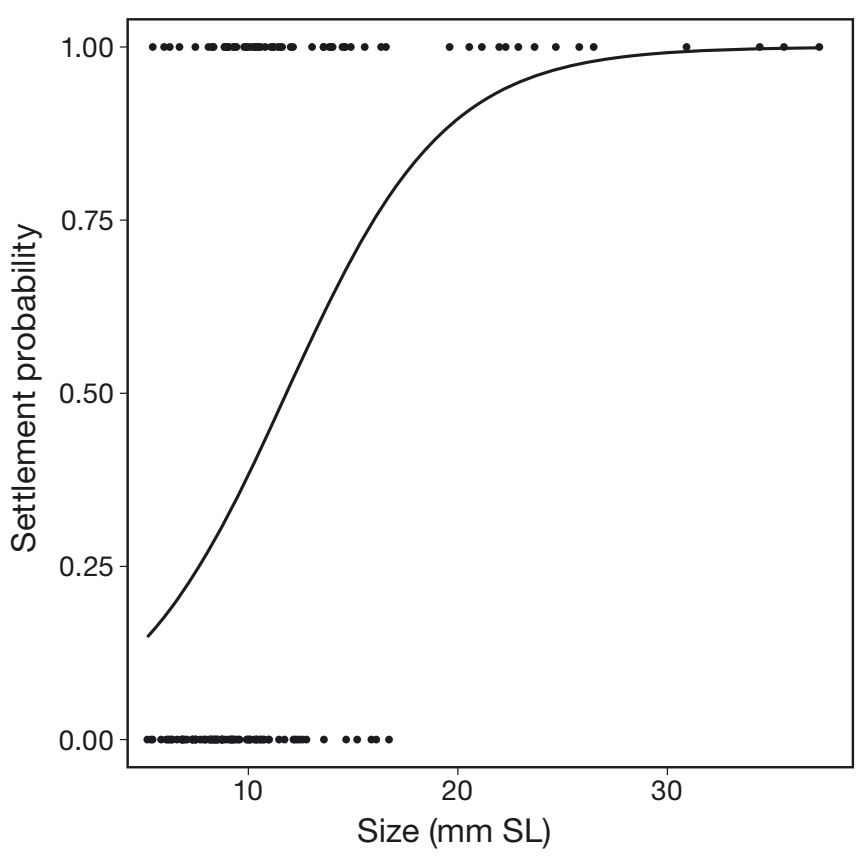

Fig. 5. Probability of red drum Sciaenops ocellatus settlement from the water column to a seagrass bed as a function of size $(p<0.001)$ in the field. Median size at settlement $(50 \%$ probability) was $12.2 \mathrm{~mm}$ SL. Points represent individuals collected from the seagrass bed (settlement probability $=1$ ) and the water column (settlement probability $=0$ )

odds of settling to the seagrass beds increased by 1.30. There was a $50 \%$ probability that a fish $12.2 \mathrm{~mm}$ SL would be found in the seagrass beds (median size at settlement).

\section{Laboratory and field comparison}

Larvae settled to seagrass beds at a similar size in the laboratory and the field $(p=0.73)$. Size was the only significant factor in the model ( $p<0.001)$; experiment location and the interaction were not significant $(\mathrm{p}=0.28)$.

\section{DISCUSSION}

Coral reef environments are overwhelmingly represented in studies of settlement in fishes (Sale 1980, Victor 1982, Sweatman 1985, Kaufman et al. 1992, Sponaugle \& Grorud-Covert 2006). Our work represents the first combined laboratory and field study of habitat attraction during settlement for an estuarinedependent subtropical and temperate species (but see Neuman \& Able 1998 for a laboratory study).
These findings show that red drum larvae are selective about the habitat to which they settle, in that they delay settlement and extend their pelagic larval duration in the presence of certain (presumably less favorable) benthic conditions. Because of this, dispersal models can be improved by considering delays in settlement depending on habitat substrate present (Lacroix et al. 2013).

Our results show that larvae transition to different habitats at different ontogenetic stages depending on the benthic structure. If they followed the 'settleand-stay' hypothesis, they should have settled to oyster shells and seagrass at the same size, and to sand at either the same or larger size (Bell \& Westoby 1986). The experimental data do not support this, so this hypothesis as the settlement model for red drum can be rejected.

Results from the field study support the hypothesis that red drum larvae delay settlement. All individuals had access to suitable habitat, and yet, while all of the larger fish were collected from the seagrass beds, many of the smaller fish remained in the water column. This could have been due to intraspecific competition within the enclosures (Nakayama et al. 2009), fear of predators within the structure, or not reaching competency (i.e. have not developed enough to take advantage of the new habitat, e.g. prey preferences have not yet shifted to a benthic environment, or their eyes have not fully developed the ability to see in lowlight environments). In a previous study on juvenile red drum, smaller individuals were found around the edges of seagrass beds while larger larvae were located closer to the center (Pérez-Domínguez 2004). The author suggested that the edges might be a transient habitat for new settlers, or that there is size-selective mortality within the seagrass beds. The horizontal distribution pattern could be influenced by the same factors that impacted the vertical distribution patterns we found. In both studies, red drum sort themselves both horizontally and vertically according to size, associating more closely with deeper seagrass as they grow.

According to stable isotope analysis, larvae switch from a diet of particulate organic matter endmembers (pelagic and detrital) to a diet of marsh plants and macroalgae end-members (benthic) at around 6 to $8 \mathrm{~mm}$ SL (Herzka et al. 2002). This indicates that larvae change their diet relatively rapidly after entering the estuaries, although our experiments suggest they might not utilize the substrate fully until approximately $12.5 \mathrm{~mm}$ SL. This size is associated with rapid changes in eye development that allow for vision in the lower light conditions 
associated with living in a shaded benthic habitat (Poling \& Fuiman 1998). These changes include an increase in the eye and lens diameter, an increase in the rod photoreceptor density, and a rapid increase in the photoreceptor:ganglion summation ratio (Fuiman \& Delbos 1998). Eye development could then be an ontogenetic milestone that needs to be met before red drum larvae can fully exploit structured habitats.

In this study, the size at settlement did not differ among larvae over the various substrates, but larvae did settle to seagrass and sand at a smaller size than they did to oyster shells. Over all substrates, some fraction of larvae left the surface at every size. Larvae of any size were likely to leave the surface over seagrass. Over sand, only the smallest larvae were likely to be found near the surface, whereas over oysters, larvae did not completely abandon the surface until they exceeded approximately $14 \mathrm{~mm}$ SL. Previous studies indicate that when juvenile red drum have a choice of substrate, they are more commonly found in structured habitats (Stunz et al. 2002a). Mean densities of new recruits ( $\leq 40 \mathrm{~mm} \mathrm{SL}$ ) are highest in seagrass beds compared with oyster shells, marsh beds (i.e. Spartina alterniflora), and unvegetated bottoms. When seagrass beds are not available, red drum are most commonly found along the marsh edge (Stunz et al. 2002a). While Stunz et al. (2002a) examined post-settlement distributions, our study on habitat attraction found similar results.

Larvae settle to oyster shells at a larger size than to either sand or seagrass, which indicates that oyster shells are a less favorable settlement habitat. While both seagrass and oyster shells provide structure, larvae delayed settlement longer over oyster shells. In the wild, this could be due to the predators and/or prey associated with each habitat, or the height or complexity of the structure (Laegdsgaard \& Johnson 2001, Gullstrom et al. 2008). Although predators were not included in this experiment, the oyster shells used in the laboratory were completely dried before the trials to remove prey prior to the trials. The seagrass, however, did not go through this process and might have contained some prey. Further studies are needed to determine the reasons for delayed settlement over oyster shells.

While this research answers fundamental questions about an important period in larval fish ecology, it also has implications for fisheries management and conservation. Seagrass beds around the world (including those used by red drum) are in decline from natural and anthropogenic effects (Short \& WyllieEcheverria 1996). For instance, Galveston Bay in Texas has seen an $80 \%$ decrease in seagrass area since the 1970s, resulting in a reduction of structurally complex habitats for post-settlement larvae (Adair et al. 1994). This study shows that red drum larvae settle to seagrass habitat at smaller sizes than to other structured benthic environments. Reduced availability of this vegetated habitat could increase predation mortality (both by extending the pelagic larval duration or increasing susceptibility over unvegetated bottoms), competition, and reduced availability of prey.

Acknowledgements. We thank W. Ludt for help with building the field enclosures and K. Perez and S. Stachelek for their field assistance, E. Oberg for help with statistics, S. Wallace and W. Tan as well as 3 anonymous reviewers for their comments. Funds were provided from the University of Texas Marine Science Institute Perry R. Bass Chair in Fisheries and Mariculture. Animal protocols were approved by the University of Texas at Austin IACUC (protocol AUP2011-00039) and field collections were conducted under Texas Parks and Wildlife Department permit SPR-1011-366. Contribution number 1707 of the University of Texas Marine Science Institute.

\section{LITERATURE CITED}

Adair SE, Moore JL, Onuf CP (1994) Distribution and status of submerged vegetation in estuaries of the upper Texas coast. Wetlands 14:110-121

Atlantic States Marine Fisheries Commission (2009) ASMFC stock assessment overview: red drum. www.asmfc.org/ uploads/file/redDrumStockAssmtSummary1209.pdf (accessed 22 March 2015)

Beck MW, Heck KL, Able KW, Childers DL and others (2001) The identification, conservation, and management of estuarine and marine nurseries for fish and invertebrates. Bioscience 51:633-641

Beckman DW, Wilson CA, Stanley AL (1988) Age and growth of red drum, Sciaenops ocellatus, from offshore waters of the northern Gulf of Mexico. Fish Bull 87:17-28

Bell JD, Westoby M (1986) Abundance of macrofauna in dense seagrass is due to habitat preference, not predation. Oecologia 68:205-209

Breitburg DL (1989) Demersal schooling prior to settlement by larvae of the naked goby. Environ Biol Fishes 26: 97-103

Butler AJ, Jernakoff P (1999) Seagrass in Australia: strategic review and development of an R\&D plan. CSIRO Publishing, Collingwood

Cowan JH Jr, Shaw RF (2002) Recruitment. In: Fuiman LA, Werner RG (eds) Fishery science: the unique contributions of early life stages. Blackwell Publishing, Oxford, p 88-111

Doherty PJ, Dufour V, Galzin R, Hixon MA, Meekan MG, Planes S (2004) High mortality during settlement is a population bottleneck for a tropical surgeonfish. Ecology 85:2422-2428

> Espino F, Tuya F, Brito A, Haroun RJ (2011) Ichthyofauna associated with Cymodocea nodosa meadows in the Canarian Archipelago (central eastern Atlantic): commu- 
nity structure and nursery role. Cienc Mar 37:157-174

Fuiman LA, Delbos BC (1998) Developmental changes in visual sensitivity of red drum, Sciaenops ocellatus. Copeia 1998:936-943

Fuiman LA, Meekan MG, McCormick MI (2010) Maladaptive behavior reinforces a recruitment bottleneck in newly settled fishes. Oecologia 164:99-108

> Gray CA, McElligott DJ, Chick RC (1996) Intra- and interestuary differences in assemblages of fishes associated with shallow seagrass and bare sand. Mar Freshw Res 47:723-735

Gullstrom M, Bodin M, Nilsson PG, Ohman MC (2008) Seagrass structural complexity and landscape configuration as determinants of tropical fish assemblage composition. Mar Ecol Prog Ser 363:241-255

> Herzka SZ, Holt SA, Holt GJ (2002) Characterization of settlement patterns of red drum Sciaenops ocellatus larvae to estuarine nursery habitat: a stable isotope approach. Mar Ecol Prog Ser 226:143-156

Hoese HD, Moore RH (1998) Fishes of the Gulf of Mexico: Texas, Louisiana, and adjacent waters, 2nd edn. Texas A\&M University Press, College Station, TX

Holt SA, Kitting CL, Arnold CR (1983) Distribution of young red drums among different sea-grass meadows. Trans Am Fish Soc 112:267-271

Holt SA, Holt GJ, Arnold CR (1989) Tidal stream transport of larval fishes into non-stratified estuaries. Rapp P-V Reun Cons Int Explor Mer 191:100-104

> Jenkins GP, Hamer PA (2001) Spatial variation in the use of seagrass and unvegetated habitats by post-settlement King George whiting (Percoidei: Sillaginidae) in relation to meiofaunal distribution and macrophyte structure. Mar Ecol Prog Ser 224:219-229

Kaufman L, Ebersole J, Beets J, McIvor CC (1992) A key phase in the recruitment dynamics of coral reef fishes: post-settlement transition. Environ Biol Fishes 34: 109-118

Lacroix G, Maes GE, Bolle LJ, Volckaert FAM (2013) Modelling dispersal dynamics of the early life stages of a marine flatfish (Solea solea L.). J Sea Res 84:13-25

> Laegdsgaard P, Johnson C (2001) Why do juvenile flatfish utilise mangrove habitats? J Exp Mar Biol Ecol 257: 229-253

Lecchini D, Carassou L, Frederich B, Nakamura Y, Mills SC, Galzin R (2012) Effects of alternate reef states on coral reef fish habitat associations. Environ Biol Fishes 94: 421-429

Lesnoff M, Lancelot R (2012) 'aod': analysis of overdispersed data. R package version $1.3 \mathrm{http}$ //CRAN.R-project.org/ package $=$ aod (accessed 10 May 2014)

Lewontin RC (1966) On the measurement of relative variability. Syst Zool 15:141-142

> Lubbers L, Boynton WR, Kemp WM (1990) Variations in structure of estuarine fish communities in relation to abundance of submersed vascular plants. Mar Ecol Prog Ser 65:1-14

> McCormick MI, Makey LJ (1997) Post-settlement transition in coral reef fishes: overlooked complexity in niche shifts. Mar Ecol Prog Ser 153:247-257

- McCormick MI, Meekan MG (2010) The importance of attitude: the influence of behaviour on survival at an ontogenetic boundary. Mar Ecol Prog Ser 407:173-185

Nagelkerken I, van der Velde G, Gorissen MW, Meijer GJ, van't Hof T, den Hartog C (2000) Importance of man- groves, seagrass beds and shallow coral reef as a nursery for important coral reef fishes, using a visual census technique. Estuar Coast Shelf Sci 51:31-44

> Nakayama S, Ojanguren AF, Fuiman LA (2009) To fight, or not to fight: determinants and consequences of social behaviour in young red drum (Sciaenops ocellatus). Behaviour 146:815-830

> Nakayama S, Ojanguren AF, Fuiman LA (2011) Processbased approach reveals directional effects of environmental factors on movement between habitats. J Anim Ecol 80:1299-1304

Neahr TA, Stunz GW, Minello TJ (2010) Habitat use patterns of newly settled spotted seatrout in estuaries of the north-western Gulf of Mexico. Fish Manag Ecol 17: 404-413

> Neuman MJ, Able KW (1998) Experimental evidence of sediment preference by early life history stages of windowpane (Scophthalmus aquosus). J Sea Res 40:33-41

> Orth RJ, Heck KL, van Montfrans J (1984) Faunal communities in seagrass beds: a review of the influence of plant structure and prey characteristics on predator-prey relationships. Estuaries 7:339-350

Pattillo ME, Czapla TE, Nelson DM, Monaco ME (1997) Distribution and abundance of fishes and invertebrates in Gulf of Mexico estuaries, Vol 2: species life history summaries. NOAA, NOS Strategic Environmental Assessments Division, Silver Spring, MD

Pérez-Domínguez R (2004) Effects of nursery-environment condition on habitat use, growth, survival and endocrine physiology during larval settlement in the red drum (Sciaenops ocellatus). PhD dissertation, The University of Texas at Austin, Port Aransas, TX

Petrik R, Levin PS, Stunz GW, Malone J (1999) Recruitment of Atlantic croaker, Micropogonias undulatus: Do postsettlement processes disrupt or reinforce initial patterns of settlement? Fish Bull 97:954-961

> Poling KR, Fuiman LA (1998) Sensory development and its relation to habitat change in three species of sciaenids. Brain Behav Evol 52:270-284

> Robertson L, Thomas P, Arnold CR (1988) Plasma cortisol and secondary stress responses of cultured red drum (Sciaenops ocellatus) to several transportation procedures. Aquaculture 68:115-130

Ruxton GD (2006) The unequal variance $t$-test is an underused alternative to Student's $t$-test and the Mann-Whitney $U$ test. Behav Ecol 17:688-690

Sale PF (1980) Assemblages of fish on patch reefs predictable or unpredictable? Environ Biol Fishes 5: 243-249

Short FT, Wyllie-Echeverria S (1996) Natural and humaninduced disturbance of seagrasses. Environ Conserv 23: $17-27$

Sogard SM (1989) Colonization of artificial seagrass by fishes and decapod crustaceans: importance of proximity to natural eelgrass. J Exp Mar Biol Ecol 133:15-37

> Sponaugle S, Grorud-Covert K (2006) Environmental variability, early life-history traits, and survival of new coral reef fish recruits. Integr Comp Biol 46:623-633

> Stunz GW, Minello TJ, Levin PS (2002a) A comparison of early juvenile red drum densities among various habitat types in Galveston Bay, Texas. Estuaries 25:76-85

Stunz GW, Minello TJ, Levin PS (2002b) Growth of newly settled red drum Sciaenops ocellatus in different estuarine habitat types. Mar Ecol Prog Ser 238:227-236 
Sweatman HPA (1985) The influence of adults of some coral reef fishes on larval recruitment. Ecol Monogr 55: 469-485

Victor BC (1982) Daily otolith increments and recruitment in two coral-reef wrasses, Thalassoma bifasciatum and Halichoeres bivittatus. Mar Biol 71:203-208

Werner EE (1988) Size, scaling, and the evolution of com-

Editorial responsibility: Christine Paetzold, Oldendorf/Luhe, Germany plex life cycles. In: Ebenman B, Persson L (eds) Sizestructured populations. Springer-Verlag, Berlin, p 60-88 White JR, McCormick MI, Meekan MG (2013) Syndromes or flexibility: behavior during a life history transition of a coral reef fish. PLoS ONE 8:e84262

Wilbur HM (1980) Complex life cycles. Annu Rev Ecol Syst 11:67-93

Submitted: November 4, 2014; Accepted: August 10, 2015 Proofs received from author(s): September 11, 2015 